\title{
Poverty and Governance-A Critical Appraisal of a Philosophy and Practice of Development in Africa
}

\author{
Ani Casimir 1,2, Emma Omeh",2, Chinedu C. Ike ${ }^{3}$ \\ ${ }^{1}$ Department of Philosophy, Institute of African Studies, University of Nigeria, Nsukka, Nigeria \\ ${ }^{2}$ Department of Philosophy, University of Nigeria, Nsukka, Nigeria \\ ${ }^{3}$ Department of Political Science, University of Nigeria, Nsukka, Nigeria \\ Email: cepperngo@yahoo.com, drommema@yahoo.com, Chinedu-ike@hotmail.com
}

Received 15 May 2014; revised 20 June 2014; accepted 1 July 2014

Copyright (C) 2014 by authors and Scientific Research Publishing Inc.

This work is licensed under the Creative Commons Attribution International License (CC BY). http://creativecommons.org/licenses/by/4.0/

(c) (†) Open Access

\section{Abstract}

The European postcolonial literature and global discourse about development concerns in Africa have witnessed a dominance of a development theory which has failed to capture the true aspirations, values and authentic problems of development confronting the people of Africa. This prowestern European theoretical framework bars African culture and values from being factored as motives, dynamics and outcomes that drive development on the continent. This absence has led to the flaunting of theories of development which favors and recommends the Breton Wood-inspired World Bank solutions/approaches to fast tracking development plans and goals in the continent. At the heart of the failure of these externally imposed prescriptions is the irreconcilability of the prospect of its resultant economic growth indicators and the production of measurable development outcomes in the lives of the people. Gross domestic product rate results in growth patterns which post impressive economic statistics; but the reality on the ground shows that there is worsening destitution and deepening poverty in household incomes, purchasing power parity and deliverables. Economic policies, engineered by good governance, lead to better management of state resources, production of pro-poor and pro-people outcomes which results in a better standard of living for the people. Bad governance has been a consistent leading contributor to increasing poverty and underdevelopment in the African continent. To reverse this scenario, there is a need to re-evaluate the conceptual framework and philosophy of development theory in post colonial Africa so as to achieve poverty reduction and good governance in the context of our cultural milieu. This re-evaluation would enable governance and the leadership to experience a shift in development paradigm that will empower development policy in Africa. My paper will therefore explore the content of this new framework and draw out its dialectical relationships and implications leading to recommendations for a new African perspective on development that will benefit Africans. These are emerging critical challenges that will definitely change the tenor and content of 
academic discourse as conceived in the philosophy of development and political economy. Development scholars, political scientists and philosophers will be compelled to re-examine the way African leaders and the so-called western consultants to Africa conceive development and underdevelopment concerns in the continent. Development is about people, so any theory or model of development should be a dialectical mirror of the way of life of a people, in an aspirational, sociological, political and technological terms and for the achievement of measureable results.

\section{Keywords}

Philosophy, Political Science, Governance, Dialectical Nexus, Paradigm Shift, African Development, Millennium, Globalization and Poverty Reduction

\section{Introduction-Philosophy and Development-Critical to Understand the Practice of Development in Africa}

There is a dialectical nexus between philosophy and development which needs further exploration with brief remarks and observations drawn from philosophy, development theory and political praxis. Philosophy is often seen traditionally as critical thinking and analysis of concepts with a view to make intellectual expositions and consistent theories that seek to explain the nature of human existence and the social challenges facing suffering humanity. To understand the theories of development-in terms of the values and principles that underpin either state policies or developmental strategies-is to understand the philosophy and development guides subscribed to leaders in governance. Each theory of development has a philosophy that explains, justifies and defines its ideological content for its subscribers and followers. Philosophy has been defined as a love of wisdom. The Concept of Philosophy must be defined to get a true idea of what development theory and practice means. However, the word philosophy comes from two Greek words namely, philos and Sophia. Philos means love of, while Sophia means wisdom. From these two Greek words, we derive the etymological or literary meaning of philosophy as "Love of Wisdom". Hence, it is not difficult in this conceptual search to see why philosophy is traditionally regarded as the "love of wisdom" or "the search for knowledge". Knowledge is necessary for human development and progress in life; but I have always posed the question- "is every knowledge or development theory wise and relevant to the solution of the challenges facing every society or cultures?” This informs the critical need to apply the critical thinking facilities of philosophy to evaluate the philosophy, theory and policies of development which had informed most development practice for the post colonial African leadership states policies and planning. In this context, the philosophical exposition of development as a multi-faceted concept is critical to our understanding of development theory and practice in Africa. Development can be defined from different perspectives but the critical point to note is that the definition depends upon the person defining it, his class interests or cultural background. The fundamental contrasting term for development is "envelopment”. Envelopment is putting of something, for instance, a letter, into an envelope. It is cover, fold or veil in. For the Etymologists, development comes from the French word, "developer". This means to bring out from the envelop something that was enveloped (Schumpeter, 1912: 22). Schumpeter in his "Theorie de Wirtschafilishcme Entwicklung" (1912), used the concept of innovation to identify development and to give it substantial axiological meaning as new creations in the lives of the people. For Schumpeter, who sees development as an experience that compares favorably to the full development of the entrepreneurial spirit in people to enable them to start something new that solves problems in their lives, innovations are symbolically both technological, economic, political and social in an individual and collective participatory sense. As innovations in people's lives, he gives both development and envelopment the name "Entwicklung" (meaning "unfolding, evolution, development”). Perroux (1964: 96) defined development as "the combination of mental and social changes of a people, which enable them to increase, cumulatively and permanently, their total real production”. He further advances that development is achieved fully in the measure that, by reciprocity of services, it prepares the way for reciprocity of consciousness. A socialist holistic definition holds that development is man's ability to appropriate his total essence in a total manner, as a whole man. It is a holistic vision in which mankind assumes control of his destiny. Ake (1996: 60) explained that development is not only based on the perspective of economic growth, 
even though economic growth in large measure determines its possibility. "Development is also not a project but a process. Development is the process by which people create and recreate themselves and their circumstances to realize higher levels of civilization in accordance with their own choices and values. Development is something that people must do for themselves, although it can be facilitated by the help of others. If people are the end of development, as is the case, they are also necessarily its agent and means. Africa and the global environment are to be taken as they are and not as they ought to be...” (Ake, 1996: 25-29).

For a development theory to work for Africa and her people, it must have sustainable values that could lead to sustainable people-development. Sustainable Development is seen as a challenge for African philosophy to enable the African people to become the originators and creators of the continent's development theory and practice. The World Commission on Environment and Development (1987: 123) defined sustainable development as development without compromising the ability of future generations to meet their own needs. Sustainable development according to Omoyibo (1998: 40) recognizes three important aspects of development namely:

1) Raising people's living level. That is, their income and consumption.

2) Creating conditions conductive to the growth of people's self-esteem through the establishment of social, political and economic system and institutions which promotes human dignity and respect.

3) Increasing people's freedom to choose by enlarging the range of their choice variables.

The idea of development for Africans recently started to gain grounds in development circles because of its vital nature in a wide range of philosophies of development that challenged the boldness of African philosophy in questioning the colonial and postcolonial inherited theories of development (Basel, 2013: ix).

According to Ketia (2013: 5) the term "development" is generally understood etymologically to mean "expansion by a process of growth" or "growth and differentiation of some entity along lines natural to its kind". According to him, what is interesting is that the progress or movement observed in social transformations was normatively viewed in moving from conditions of being less developed to ones of being more developed. One recalls Marx's quasi-Darwinian thesis that human history was naturally evolutionary progressing from less developed stages to those that were more developed. Thus, for Marx, a developed capitalism would eventually give way to socialism then communism, eventually reflective of a mature human society. As Ketia observed, another interesting point about Hegel's "dialectics of history" is that "his philosophy of history granted no developmental path for Africa. Africa, according Hegel, had not entered into the path of human history, therefore it did not contain the necessary criteria for development. In this regard, Africa would be permanently undeveloped". European societies are in the process of development just as other societies deemed "undeveloped" or "developing". Thus, every society has its cultural dynamics that, if properly managed by its leadership and its people, could lead to measureable and sustainable results as higher standards drawn from their own self-created philosophy and paradigm. For this reason, the automatic contrast between "developed" and "developing” societies should be subject to debate. To challenge this theory and to expose its theoretical bias and emptiness is part of the philosophical tasks embedded in this research article.

\section{The Concept of Development and the African Personality—An Exposition}

Development cannot be considered in isolation of what it means to be African, who we are, what we are and what we hope for. To be able to tackle the critical need for an African paradigm shift we ought to re-evaluate certain overhanging issues relative to pre-colonial Africa, colonial Africa and post colonial Africa. According to Njoku (2004: 610), before we can understand the present developmental problems and concerns that bedevil African people in the $21^{\text {st }}$ century we should clarify fundamental philosophical and preliminary issues which cast great doubts about the concept, identity, potentials, aspirations and problems experienced by the people of Africa at the onset of the European scramble for Africa which ended with colonial exploitation, denigration and domination of Africa and Africans. Several theories of Philosophy and development, both of African and non African origin, have emerged recently to explain the dilemma of underdevelopment in the midst of huge natural and mineral resources. To appreciate why Africa's social reality is filled with so much contradictions of underdevelopment and unfulfilled promises of development a lot explanatory frameworks have been offered. Professor Onyeocha (2011: 15) in his book Africa - the country, the concept and the Horizon hits the nail on the head with his revealing conceptual clarification of the features of the African reality, which according to this writer must precede all issues concerning Africa:

There is some effort to define and delineate as clearly as possible the various issues involved in the study of 
Africa. In this regard the reality that is Africa can be considered as geographic locale, in which the physical, climatic can be considered. Africa can also be considered as an ideological concept in terms of its characteristics as a socio-cultural and political entity (Chachage, 1994: 51). In such a case, the various political, religious and philosophical elements involved would be given primary consideration.

From Professor Onyeocha we can immediately glean the fact that we need a wholesome redefinition of what it means to be an African. He posits the suggestion that the true African must be concerned about the development of his potentials and the fulfillment of the societal aspirations of the people. He is an authentic being who must be involved with searching for a new paradigm for the sustainable solution of development concerns. This individual involvement at the intellectual level leads him to the search for new models and paradigms for solving the stubborn problems of under-development in Africa (Blomstrom, 1978: 14). For too long, western-based European analysis of development in Africa has been based on a jaundiced and inferior framework that denies integrity and creativity to the African intellectual process with the consequent denial of African intellectual participation in the debate. There is an acceptable hunger for this African perspective on who is an African, what is it to be African and what are the aspirations of the African society in terms of the millennium development needs of the Continent. Accordingly, Onyeocha (2011: xi) observes that:

The African... is, without doubt, better placed than anyone else, to discuss African issues from direct lived experience, and to present African viewpoints authoritively, comprehensively, and with the greatest understanding. More than anyone else, the African... is able to present Africa to the world from within, is able to engender empathy for her cause, and enable her to be understood from the inside... to present the world from the African viewpoint i.e. as the African sees it and functions in it.

In contrast to this new search for original ideas and conceptions as to his place in the economy of the world is a concept of the African loaded with the denial of primordiality, originality, ontology and creativity to his intellectual strivings and productions. Till today, the tragedy of the African colonial, neo-colonial and post colonial experience, especially on development, is that the Europeans left the African with a jaundiced and stereotyped ideas about the African personality's conception of his needs, problems and even aspirations. That colonial disaster has become even a millennium virus which has infected everything African, including his perspective on development, poverty reduction, governance and general political economy. The African in this neo-colonial and millennial asphyxiations has a bad image of himself after his colonial trauma. From the Hegelian negative projections about the inability of the African for self development in his thinking and societal efforts, it is easy to appreciate the extent and depth of this trauma.

The great conundrum of a paradigm shift on African development theory is that it must start with "a good and balanced portrait of Africa” as the beginning of the search for the African indigenous meaning of development and how he can use the cultural rootedness of the idea to solve problems of bad governance, poverty reduction and pervasive under development in Africa (Adedeji, 1996: 21). pan Africanism, at best, embodied the metaphysical, cultural, social, political, economic, and sociological synergy of attributes that define who is an indigenous African, what he wants in development and what should be the self-defined benchmarks for setting standards for development goals, policies, monitors, evaluations and benchmarking his levels of performance or underperformance. In its sharp outlines, pan Africanism according to Onyeocha (2011: 18) presupposes that:

1) Africa is the homeland of Africans and persons of African descent. Thus pan Africanism aims at the regeneration of Africa and the promotion of a feeling of oneness and solidarity among the peoples of the African world;

2) The African past, including its culture and traditions, must be recognized and rehabilitated. This does not necessarily rule out openness to new ideas and new developments in the world around Africa;

3) Pan Africanism has the vision of a united and glorious Africa that would hold its own in the world. It would frown at any ideas that would create obstacles and artificial barriers to separate Africa's children from each other;

4) It operates on a central ingredient of solidarity among people of African extraction whether they are at home in Africa or find themselves abroad in the Diaspora. It considers them as endowed with a distinct "African personality";

5) It glorifies the African past and inculcates pride in African values.

Thus, the need to reposition the African developmental rehabilitation, reinvention and reintegration with an 
authentic theory of development that is attuned with development dynamics of a fast changing global economy must be situated within the context of the "Trinity" question and matrix of African development which is seen by Esedese(1978: 76) in his "The Emergence of pan African ideas in themes in African social and political thought' as "concerning what one is, an economist interest in Africa is deferent from a historian's, or a business person's, or a missionary's... concerning what one has, the intellectual tool in terms of personal education is an important factor... concerning what one wants... there are material financial interests as contrasted to spiritual or intellectual or cultural, or ideological interests. Each provides its own twists to the question of Africa".

The article took time to explore the African personality and what he wants in development related to Africa governance and poverty reduction because it is central to the determination of the basic issues of the wellbeing of the African and the indigenous ethical, philosophical, socio-economic and political values cherished by him in his African political philosophy and development practice. These philosophical issues and concerns about the African are relevant to the creation of a new conception and theory of development that will represent a paradigmatic shift in the way Africans themselves seek to achieve good governance, development and poverty reduction in the millenium. Most fundamentally, it is as a result of the critical consideration of the position of Peers (1972: 91) who, in posing the question "what are we trying to measure" in development that helps us to have an insight which links the human personality and development concerns, the desires and needs of the African since, according, to him:

Development means creating the conditions for the realization of the human personality. Development has a lot to do with the African personality and what he wants in life. Moreover, it is important to put into cultural and philosophical context a re-evaluation of how African philosophers have viewed the question of development and underdevelopment in Africa.

Finally, it is of great academic, conceptual and dialectical interest to critically reflect on the recommendations that have emanated from scholars of African political economy as a new theory of development with huge impact on governance, anti-corruption and poverty reduction. These recommendations will be politically and economically innovative when placed side by side with the new poverty reduction strategic papers drawn by African governments to attract European economic sponsorships and financial aid. It has become necessary to expose this deceptive interest propelled by western monetary gratification in view of the fact that one hardly finds African perspectives reflected in the model theories of development in general which are on the main dominated by the class economic interests of the ruling elites in Africa. The academic wave to redefine the African and his aspirations in life has affected and expanded the interests and precincts of African philosophy, African jurisprudence and is presently invading the halls of development to determine and re-determine the content of what has for long been fed to Africans as development theory. Thus we can happily say that "Placide Temples" Bantu philosophy (Temples, 1976: 80) and that of Dukor's theistic humanism (Dukor, 2010: 81) together constitute a watershed in the current endeavors to come out with what would be considered as African philosophy of development with a global recognition. This means that within the context of this newly re-appropriated African philosophy which was filled with a new synergy to redefine the old ways, shatter euro-centric stereotypes about Africa and her aspirations, African scholars can design the outlines of a new development paradigm which will empower Africans with a millennium theory of development and governance. We are therefore creating the framework for a new philosophy of development that will make cultural, sociological, political, psychological, economic and technological meaning to the African development scholars and those who are interested in reducing poverty in the continent.

\section{Development-An African Paradigm Shift}

\subsection{What Is Development and What Is Underdevelopment?}

If we must truly answer these twin questions-one dialectically linked to the other, then we must appreciate the principles of evolution which have guided, step by step, the African conception of development. The highlights of this evolution could be described in the following highlights:

1) African philosophy has emerged in full force as a global system of philosophy;

2) The controversy concerning the existence or not of African philosophy has ended;

3) The evolution of its value framework and content has moved away from the verstiges of Bantu philosophy, negritude, communalism and pan Africanism; 
4) It is currently investing all human disciplines with a value chain which is cultural, creative, psychological, economic, religious, technological and developmental.

I can affirm and confirm with other philosophers in the African continent that "African philosophy-(as a framework for a new development paradigm)-has broadened in terms of its horizon and is currently treated as a methodological inquiry with the same universal aims as those of any other philosophy in the world (Hountondy, 1983: 102). Having ended the controversy concerning the existence or non-existence of African philosophy, the question naturally arises-what great intellectual and theoretical reformulations have African scholars wrought with millennium issues which are being used by the west to foist a new academic colonialism upon the continent? (Moses, 2007: 21). Generally, African philosophers such as Nzongola \& Ntalaja (1989: 118) have a new theory of development which attributed the major obstacle to any meaningful (development) and transformation in Africa, and hence its socio-economic hardships to the fact that the civil societies in Africa have been socially and politically marginalized organizationally in the post independence and post colonial African state (Samuel, 1998: 43). Simultaneous with this process was the strengthening of the state apparati of governmental organizations, institutions and public policy. In other words, the socio-economic crisis facing Africa today is that the neo-colonial state itself constitutes the major obstacle to development. People have been left defenseless vis-à-vis these states and cannot fight against the arbitrary actions of the state or defend their living standards... thus the issue being that of the creation of democratic forms of governance in Africa.

Democracy has been linked to development while dictatorship has been linked to underdevelopment and poverty. But one salient point we ought to point out is the fact that it is part of the study by African philosophers on development problems in Africa that we need a new paradigm shift even in the way we see democracy. Sadly, democracy in Africa has raised the specter of a new dictatorship since its practice is still anchored upon the whims of selfish leaders who operate a European-filled state structure which mismanages the resources of Africa through wholesale brigandage and corruption. In the new millennium, democracy is still under a dictatorship of a corrupt state structure with the non-participation, non-involvement and non-commitment of the African civil society. The African state is still filled with the neo-colonial vestiges in which selfish individual leaders continue to exploit the people through the agency of the state after they have been voted into power. In Africa people are denied their mandates, people's votes are blatantly stolen in broad light, bribery and corruption determine electoral authority and victory. Seen only periodically, the new elected leaders are seen more often by the people with their corrupt and stolen trappings of power while the African masses wallow deeper into a poverty crisis which have made the continent a basket case and one of the ironic inspirations why the millennium development goals was started in the first place.

The quest for true democracy in Africa would truly have arrived, and can only thrive when there is free, fair, people-based peaceful elections, an independent judiciary, a non-corrupt state executive and a public policy participatory framework which will be pro-people, pro-poor and pro-Africa in its development content. Ironically, it is not only in military regimes you have African dictatorships. We know too well from our experiences in so many African democracies, some as recent as 2008 and 2011 in Nigeria, and in 2014 in Egypt that we have unrepentant democratic dictators who are obsessed with pro-longed unconstitutional tenures so they can continue to be in power and swindle African state resources. In essence, the search of a new development paradigm must include a serious philosophical enquiry on how we can invest African democracy with African people values which we can use to straighten our democracy and establish it as an authentic instrument and tool of designing African development goals, programs and policies to reduce poverty in Africa, in real terms. The picture painted by Oruka (1985: 117-118) supports this scenario:

The average man and woman in Africa in the new millennium is poor, not because Africa is not blessed with abundant resources and man power, but because we live in what the philosopher Oruka calls "an uncivil republic where the state structures and institutions bequeathed to us by colonialism are still used by selfish leaders who use the democratic votes stolen from the people to even isolate them from policy formulation, execution, monitoring and impact assessment. In summary, the civil society-the new name for the African "ummunna" or value for collective leadership filled with a social conscience for the common good and welfare; that prevents corruption or brings shame and removal to corrupt leaders, but which, sadly-is not empowered in today's democracy. As a result, is it any wonder that the stored energies and synergies of the African people remained untapped, unmoved and un-mobilized for charting authentic development concerns and paths in the continent? Need we search any further why despite billions of dollars 
accruing to the sates in Africa, annually, African poverty still remains the embarrassing target and subject of poverty reduction in United Nations?

The failure of the African states even in the millennium democratic dispensation should now convince us that we need a new paradigm for a development theory which will inject a refreshing African cultural content into our democracy and governance since they constitute the major instruments for planning development in the continent. So much for critical thinking on African development. Rather than just posing questions about the concept of development as it concerns Africa, we need also to step out of philosophy in order to meet and dialogue with social reality. It will give us a new concept for development after we have concluded our dialogue among ourselves. This new conception of development for African transformation is discernible in the debates among African philosophers. The thrust of the debate according to Mudimbe (1984) is as follows: "The way out of African underdevelopment is to broaden and indigenize democracy, empower civil society and... less economism, technologism and structuralism... and concentrate more on the whole question of conditions for self-organization of the African masses for the total transformation of African societies".

\subsection{Why Do We Need New Paradigms Shift in African Development?}

There is no doubt that there is a development crisis in the African continent. Bad governance, corruption, poverty, disease, wars, conflicts, continental retardation and continuous under utilization of our human and natural resources have led our people to question the scholarship of Eurocentric theories of development with which African leaders have struggled, without success, to develop the continent. The failure has brought about an organized search from social scientists who had been studying development concerns in the continent for several decades. In recent years, a paradigm crisis has led to non-acceptance, half acceptance, mixed acceptance and even outright rejection of the old euro-centred paradigm for the study of development in Africa. Ulf Himmelstrand, Kabiru Kinyanjui, Edward Mbirugu, Dr. Etuk, and Monsignor professor Obiora Ike were members of a band of global scholars that defined a new project known as "In Search of New Paradigms for the study of African Development” ((SENPAD) Himmelstrand et al., 1988: 48-57; Obiora, 2000: 1-3). Resolving the paradigm crisis in African development theory must be resolved, not in the context of a completely Khunian revolution as happens in the sciences but, as in the social sciences, by "a search for a synthesis of past perspective when old ideas can be combined in a new manner". It is critical that the philosophical rigor of this paradigmatic demand on a new development theory should be outlined clearly. When we use the term paradigm we are using it within a special emphasis on certain concepts and objects of knowledge on emphasis that could expressed in terms of three philosophical molds, viz:

1) a specific selection of variables and objects of knowledge;

3) a specific selection of analytical and empirical research methods;

4) and perhaps in terms of the kind of praxis or application favored.

To avoid being nebulous in their search, the team's use of the new paradigm concept focused upon six queries but I will focus on only two as directly relevant to my paper.

\subsection{Queries on African Development}

1) What is the nature of the relationship between competing or otherwise diverse paradigms and perspectives in the social sciences that endeavour to understand and explain African development? Are they compatible?

2) Finally, is it possible to move beyond the controversies found in the literature on African development, in search of new, more comprehensive, relevant and empirically sound approaches?

Without doubt these queries have continued to determine the subject and context of different conferences concerning new directions for African development in the context of millennium challenges for poverty reduction and demands for good governance in the continent. At issue here is the confrontation between two values systems in studying African development concerns. At one end is a Eurocentric humane, free, valueless, "scientific" analytical framework of studying African development which has been exposed as biased and does not assist in solving the African predicament covering underdevelopment. Throwing more light in this European based theoretical model has been necessary to understand why the western institutions that buy into their theories cannot do much to help African underdevelopment predicament. It is necessary to see why we believe that a predicament free analysis is closely associated with so-called value free science which usually is not value free at all but 
is studying social and human reality from a hegemonic value system of ideological establishments, western or indigenous. In contrast is the Afro-centric view which is pro-people, pro-culture and pro-growth which is according to the collective views of Okere/Ike/Oyegocha (ibid) could be defined by the as a predicament-oriented social science approach (that) endeavors to attain two units of knowledge-first a local understanding of the nature of given predicaments among those facing these predicaments in their daily lives, a type of knowledge which perhaps could be attained with some kind of participating action-research and a knowledge of the broader historical, structural and ecological causes generating such predicaments... The kind of local level to illuminate the understanding from below of the predicaments confronted there, and to provide guidelines for local action and struggle.

3) Africans defining development and underdevelopment: exploring the millenization of African development study.

There is no doubt that global ideological perspectives with Eurocentric value system have influenced the process of interaction, scholarship and theories of socio-economic development in Africa (Cribson, 1961: 49-50). From 1950 to the modern period social scientists in Africa also took their lead from these models many of which concentrated upon structural functionalism, modernization, neo-Marxist political economy and neo-liberal Euro doctrines/ World Bank theories. It is not just enough to take these leads in theoretical formulation, criticize them or throw them away. African scholars are increasingly abstracting what is relevant to Africa from these models and emerging with new brave and creative theories to move development forward in the continent. Marxist scholars are becoming increasingly frustrated for want of a soviet union and other Marxist state models. The issue however is not just to concern ourselves with first throwing out or accepting outside theories of development but evolving synergistic creation borne from the pan African sense of what is Africa, what Africa has and what Africa wants in the context of the modernization theory of sustainable growth, trade liberalization and the threats of globalization to swallow Africa. Furthermore, present African leaders have continued to depend upon development prescriptions which do not involve the people of Africa but impose foreign modeled structural conditioning which are half-baked and serve, at best, only the economic and political empowerment of the African elite. African scholars are increasingly abstracting what is relevant to Africa from these models and emerging with new brave and creative theories to move development forward in the continent.

I willingly call this creative pro-people approach the millenization of African development scholarship. Millenization is different from westernization nor communism; to have more clarity on this idea of millenization framework it is more akin to a new concept of modernization which must be formulated from the vantage point of African predicaments as an analysis of ways for overcoming the problems which so far have brought stagnation, inefficiency and increasing inequalities than progress into more efficient and socially acceptable economic/ political practise for Africa. Secondly, millenization also means that western European social science with all its insights and knowledge is insufficient for an analysis, understanding and explanation of African conditions, present and future. Millenization means that African social scientists can learn a great deal from some aspects of western minded theories and then integrate them with an African-based perspective which will Africanize the study.

But the first identified problem of development is a traceable to intellectual or conceptual poverty seen as the laziness or indolence of scholars to generate new workable and creative ideas or theories to solve problems that are challenging the continent in the millenium. Our intellectualls will rather imbibe western ideas and theories and even distort and misapply them to African developments despite the fact that they were conceived in a socio-cultural environment that are foreign to the needs of the continent. The African continent has become, as a result, the grave yard of incipient creativity and unfermented ideas.

Most often than not, we tend to overlook or take for granted what we have in Africa when we are carrying out analysis of what caused the African condition and how we can get out of it. Secondly, we look outwards first, before, after repeated failures of the foreign models, rather than to look inwards to seek for minor solutions to the problems of development in Africa.

Thirdly, it will be naïve to keep pointing all the time upon Europe as the only cause of our problems of underdevelopment. Africans, as military and civilian dictators, also led to the problems of Africa. Fourthly, the metaphor of "Africare" (Izu: 2010: 23) reveals the powerful epistemology of a self-reliant indigenous inquiry about the causes and solutions to our underdevelopment in Africa. Self-reliant epistemology and theistic human values (Dukor, 2010) suddenly reveal a new window of causes and solutions which had been overlooked because we had focused upon the wrong approaches and used the wrong inherited paradigm of colonialism which 
is mostly a top-down and anti-people framework in the continent. The direct implications says we must come up with a new theory perspective that will take African values, peoples and aspirations into consideration when we are attempting to solve underdevelopment in the continent. This challenge naturally takes us to the question: What Is the Problem with African Development? To answer this question will assist us to appreciate how the African sees development and underdevelopment. The first critical response to that enquiry comes from the problems of understanding and domestication of the old development paradigm created and fostered upon Africa by the colonial, neocolonial and neoliberal development policies imposed upon the peoples of Africa. Most importantly, these paradigms and their consequent development policies adopted by states in Africa failed repeatedly to lift Africa out of poverty. Just like other western inspired development models and policies in Africa, the Nigerian economic empowerment development strategic document (NEEDS, 2003: 42) did not work fully because of its non-inclusion of a cultural content and the exclusion of the African civil society in real terms to define what needs to be developed, how they should be development, when they should be developed and the manner such development dynamic could lead to direct improvements in the living standards of Africa's majority. Thus we need to know from the foregoing that the bad governance practice of excluding the people from government and development has deep roots from colonialism, neo-colonialism and the globalization. They serve to emaciate the will; mind and consciousness of the people eulogize anti-people policies and institutionalize a pro-western values system that imposes development frameworks upon the African people.

4) The Failure of NEEDS and Globalization: A critical analysis of the Breton Wood-inspired Poverty reduction strategy document.

Why did such poverty reduction strategy documents like Nigeria's National Economic Empowerment Development Strategy (NEEDS, 2003: 20) failed to achieve its pro-growth and pro-people development goals and objectives? In the middle of the 1990s, the World Bank made it compulsory for developing countries in and outside Africa to come up with a home grown, pro-people, and pro-poor strategy to generate development gains and reduce poverty in real terms. The ruling elites in Africa only started writing theirs only when they knew that there would not be any development assistance or debt cancellation for them without the production, submission and approval of such a document to the World Bank. As soon as the leaders were given the money based upon the development templates in the document they would direct the money to other areas of the economy and claim economic contigency or a social emergency. But the faults of this approach are manifold. The documents were not produced from a bottom-up, pro-people and pro-poor perspective. The members of the panel that produced the document only "consulted" the people's representatives who have the most forceful media and political presence in their countries and claimed to be the voice and views of the grassroots.

Secondly, the civil society in Africa was marginalized before, during and after the production of the document meant for African development and recovery. As non-governmental organizations, (NGOS), faith-based organizations (FBOS), labor unions, they remain the modern symbolic and social face of the "Umunna" in precolonial Africa political economy which reflected a communal value and synergy which only can describe a development plan as pro-people. Thirdly, having excluded the members of the civil society, the authentic voice of the African people in governance, the governments of Africa also made sure that in some places where civil society were hesitatingly allowed in program formulation they were not given budgeted resources to be part of implementation, evaluation and monitoring of the impact of government development policy on poverty. Finally, even when such development policies have failed—since they bring about only economic growth in Africa—we still have the problem of globalization since it is another platform for the old scramble to partition and share Africa by the Europeans. As observed by Professor Ike (2008: 102) in his work globalization: where is Africa's future:

Neo-liberalization is moving ahead at high speed, together with economic globalization. It is essential to take a look at this economic system and to guarantee people's participation in decision, which affects their lives. By emphasizing short-term gain and the unlimited accumulation of profits, neo-liberalization, the current economic model, neglects people's needs. While it is true that neo-liberalization produces wealth, it distributes it unequitably. More than ever, Multinational Corporation are scouring the planet in search of cheap lab our and low production costs.

Paralled to the growth of multinationals is the ability of investors to instantly move billions of dollars from one part of the planet to another with the sole objective of speculation and without government regulation of any sort. In fact, governments have become unreasonably vulnerable to the notions of financial markets, competiting with one another to attract foreign capital. This development model is deeply flawed. It represents poverty, un- 
employment and marginalization for billions of people. To achieve true human development, we must move beyond symptoms and examine the root cause of today's problems... Throughout the world, increasing numbers of economists, social scientists, social justice groups and labor organizations are denouncing the inequalities produced by the present[western]development model, with studies and statistics to support them.

Globalization has become another name for the economic exploitation of Africa and the intimidation of its intellectual human resources, institutions from searching for and using its own homegrown culture-injected framework for genuine development initiatives in Africa. This is because if one were to read between the lines within the towering speeches and theories put forward to defend globalization and why Africa should embrace it, we will still see the hands of a European-centred development model and theory which have taken Africa to no destination for decades since political independence. We need to expose further the origin of modern globalization. As noted by Areji (2005: 13):

Euro centricity and globalization... are historically situated. They are products of racial bigotry, slave trade, colonialism and a feeling of superiority. The west enslaved African for so many years through the transAtlantic slave trade. This is physical and social slavery. When slave trade was abolished, another form of slavery was introduced-political slavery [colonialism]. In an attempt to justify their injustices, the Europeans propounded negative theories against Africans. When independence was won, a new form of ideology was propounded to continue the enslavement of Africans. This marked the birth of globalization.

Essentially, we have argued that the new African development paradigm should be integrative of beneficent and culturally compliant concepts which are relevant to African aspirations. But before we can succeed in reevaluating globalization we need to properly design a new theoritical framework that will overthrow Breton Wood inspired development theory for understanding African underdevelopment since, according to Nwoye (2000: 50):

The actual problem that faces a theoritician of African development theory today is the pragramatic question-what is still authentically African after centuries of slavery, colonialism and neocolonialism? Put differently, does Africa need to reject western civilization in her search for authentic African values. The position of this paper is that politics and development can attain to the desire end, if only they derive from the culture and natural instincts and sensibilities of a people. For this, capitalism and marxism — two allied evils - are totally unacceptable to the African natural disposition. All African political theoriticians and philosophers are agreed on African socialism as the authentic political economy for Africa. This is the view of Senghor [negritude], Nyerere [ujamaa], Kaunda [African humanism], Nkrumah [philosophical consciencism], and Nnamdi Azikiwe [pan Africanism]. All these socio-economic theories have one thing in common-the preservation of African communitarian values... and outlook that are authentically African. This is however, not say that these theories are against western civilization in every sense. What they wish to suggest is an assimilation of the vital elements in western civilization with authentic and living values. This merger would bring about a development theory for Africa.

From the time of colonialism, neocolonialism and to the margins of the 21st century, the average African man or woman has undergone several degrees of worsening destitution and poverty all because of a capitalist and neocolonial economic theory and system which has mismanaged Africa's political economy. The state in Africa is ruled by a corrupt and autocratic elite who have made it their business of governance to pauperize the poor, marginalize the people and waste the resources of Africa. The economic and social crisis in the continent have generated massive academic and development debate which has spawned huge research work on African development concerns. Nwoye Kenneth Ogechukwu (2000: 41), writing under the book: The nature and features of African development, gives an analytical perspective crisis:

The reason for this controversy stems primarily from the abysmal performance of most African countries. With the exceptions of countries like South Africa, Ghana, others are either stagnating or are caught up in one nasty and intractable political and social crisis. In most African countries gross national product per person are among the lowest in the world. The implication is that majority of African citizens contribute little or nothing to global economic growth. The reasons for this disastrous state of affairs are many. The first reason is traceable to repressive and kleptocratic authoritarian regimes that have virtually alienated the mass of Africans from governance over the past years. The second reason relates to incessant conflicts that 
are so widespread and unrelenting in the continent. Under this situation of instability and anarchy, development in whatever form cannot place... The third reason is that the African continent as a whole is being increasingly marginalized economically as a result of the changing global economy. The world trade organization [WTO] with its unjust trading policies and the highly protectionist measures being put in place as result European economic unification all combined to compose severe economic challenges for Africa.

5) Government/Develoment structures in Africa: rooted in Neocolonial and Capitalistic exploitation.

The present crops of leaders in Africa are predominantly products of colonial and neocolonial exploitation. Poised between the values of western Europe and the African communal values they are facing a dilemma which has paralyzed them from being capable of meeting up with the challenges of governing Africa and reducing its poverty. Today's African elites are to be found in all spheres of the African political economy assuming the toga of good imitative postures of western European models in everything they are doing in the continent. The typical elite is worth a deliberate study as factor in the underdevelopment of Africa since colonialism. He is the one championing the theoretical values of Eurocentric concept of development and the description of all forms of African theoretical frameworks as primitive and ineffectual in transforming Africa. This a tragedy-Africans being in the forefront of condemning original thinking in the attempt to better the fate of Africa! Meanwhile he very much romanticizes the western model of development and recommends it, without chewing and digesting, to Africa. However, his counterparts in the political terrain are crushed by his own paralysis in translating that theory into workable models and theories for developing Africa. He has a theoretical model imposed upon him hich he uses for development planning but which, unfortunately, does not produce results in solving the development problems of Africa. There is a gap between western theory and policies as against African developmental needs. So as a result of the gap between theory and action, ineffectuality of the * inspired models, the political elite is sandwiched between throwing up in defeat and joining in the search for an African theory of development or rigging elections and, when he gets to power (most times through a stolen electoral mandate) establish a most brazen form of corrupt governance which will steal misapply and misapply and misappropriate resources belonging to African people. He chooses the latter.

African governance is in the hands of individuals who had no genuine interest in developing the continent. The state is in the hands of those who plunder its resources and deliberately send African peoples into the deep ocean of destitution and vicious poverty. On getting to power, they first marginalize the people by removing them from the governance structure. African peoples were used to a criminal system of governance which is fundamentally collective and pro-people. In Igbo-land of Africa, this system is the "Umunna collegiate ruling system" whose synergy steam and dynamics come from what is "Igwebuike-the people is the power": the power and strength to be transparent to manage resources, to determine the needs of the people in development, their future aspirations and the mechanism for getting at their targets and measuring when they have gotten there. But as a result of colonialism, those in government today, like the colonialists before, are afraid of the people getting close to government hose and knowing how peoples' resources are stolen and diverted into private pockets. When people are distanced and marginalized from governance, there cannot be any development because, according to Professor Obiora Ike (2003: 85), development is about people:

If, therefore, we do not want to waste more decades, it is time to agree on a working definition of development in which we want people to be fully involved. I fully agree with the definition given by the participants of the 4th National Theological week het at Katigondo, January, 1989, which said that "While in the past, development was principally understood in terms of economic progress, we have now realized and become convinced that appropriate progress should be integral development”. Such development must cater for the whole human person and encompass the people of the nation as a whole by developing their spiritual, religious social, personal, moral, cultural, economic, political, mental, educational, physical and environment dimensions. Such then is the development in which we want people to be fully involved in its identification, planning, implementation and evaluation at every level and phase. Such is the development that can liberate Africa and other oppressed continents. It is the only development worth planning and can bring hope to the millions of the suffering people of the world.

However, good governance in a democracy is about a good leader who can design policy programs which are injected with the framework of African development theory such being as pro-people, pro-poor and pro-open in its formulations, implementation, evaluation and monitoring system. Being pro-people for example, is a function 
of good governance and as we have seen, it is the only governance structure that can create the enabling environment for an Afro-centric development to take place. It is the only governance structure which can deliver authentic development goals, benefits and dividends to the people of Africa. Good governance has a corollary in bad governance. Bad governance contributes to African under-development through corruption and selfish exclusive socio-economic policies which exclude the people from governance. The only time the African people are involved in governance is when the elite call upon them to votes during periodic elections; after which they will disappear within the cozy palace of the government house. Bad governance seizes, demobilizes and restricts the African potentials for development because of a blind acceptance of every economic and social development model/policy coming from Europe. Under guise of joining the rest of Europe in a flushed globalized world, they impose anti-people economic formulas which distort the standards of living of the people and lead to worsening of poverty levels in the continent.

\section{Africa and the Modern-Day Crisis of Development}

The Commonwealth leaders' observation (2008: 1-2) of a critical need for reform in the management system and prescription of the Breton Woods Institutions have said a lot about Africa and the crisis of under-development:

African continent as a whole is going through a long and debilitating political and economic crisis. The worst hit appears to the sub-Saharan region which has continued to suffer severe economic stagnation and protracted debt crisis. It is a crisis of unprecedented proportions manifested in abysmal decline in overall living standards and in decaying infrastructures and acute poverty. The implication of the above... is that Africa is in a serious political and economic quagmire that will require extraordinary will, courage, tenacity and severity of leadership if the contentment is going to meet the challenges of the new millenium.

What the common wealth leaders have condemned as weaknesses in the Bretton Woods imposed development theories, policies and prescriptions, other African development scholars interested in millenization have also recommended, albeit with a different phraseology, as the crisis in development in Africa. Nwoye comments: "It is not necessary to clamor for reforms and call for an new model for development in Africa and other developing countries, why did the Commonwealth interested in putting pressures in changing the way IMF-World Bank made European centred prescriptions for managing African economies why are they meeting to deliberate on how to change these Institutions' to reflect more the values and development aspirations of the African peoples? When I made a case for the African millenization of development values, needs and goals beginning with a new development paradigm. I was happening on a new model that will also change and reform the framework, content and system for African governance structure to bring about new African values and pro-people style in the way we manage our economies and solve development problems such as poverty. The Commonwealth position became clearer when they noted that leaders of developing countries do not have the freedom to determining national goals and do have the capacity to genuinely manage their people's economies. Nwoye agrees and observes further:

Sovereign states must have the capacity and freedom to determine national goals and implement national policies and strategies adding that many national goals could not be achieved. The glaring failure of the development project in Africa has continued to provide ample room for all kinds of dubious and misguided development programs all in the name of turning Africa around the most potent of these programs in recent years has been the structural adjustment program (SAP). Sponsored by the IMF-World Bank. This programme has become so... damaging to African countries that it has led to severe riots, insurrections and even economic collapse 41.

Professor Ayo Adedeji agrees with Nwoye that: "after a decade and more of Structural Adjustment Programmes, poverty has become more pervasive and systematic in Africa, and is predicted to grow especially in sub-Saharan Africa as far into the twenty-first century as current projections reach”. Nwoye has also succeeded in buttressing up the contribution of Professor Ake (1996: 13-15) to this Euro-centric style of recommending harsh un-African and anti-people development policies for African economies:

The Structural Adjustment Programs (SAP) that African countries have to adopt are compounding the weakness of the State in Africa owing to their one-sided emphasis on privatization, commercialization and reliance and market forces. These problems are weakening the State even politically and structurally. They 
are so drastic and so severe in their impact that they engender hostility to the state and undermine its limited legitimacy.

As corroborated by the Commonwealth observations and reports in 2008, even the World Bank report recently accepted that development prescriptions based upon neoliberalism and the vestiges of neocolonialism cannot turn Africa around, much less develop it. What does this imply? It means that we should work harder in the millenialization of a home-grown, bottom-up and people oriented cultural development framework that will become an authentic reflection of African peoples' past needs, problems and aspiration. We need a people-centred enclosure of the new African millenization of development concerns in the millenium to end poverty on the continent. Though the World Bank called this “adjustment with a human face”, Nwoye's delineation of this development typology is much more perspicacious when he draws out more implications:

The implication is that the Structural Adjustment Program has failed completely to turn Africa around except to plunge the continent into deeper and unrelenting misery and hardship. In recent years, the world bank has openly accepted the hopelessness of its economic therapy in its subsequent development reports that call for adjustment with a human face. "The central position is that economic policies must beyond 'adjustment' to issues such as population growth, environment, institutions, technology as well as the social and political dimensions of development... the evident failure is reflected in the changed position of the world bank now interested in sustainable and people-oriented development approach opposed to the use of competitive-domestic/external market forces”.

\section{What Caused Poverty and Other Crisis of African Development?}

According to Professor Adedeji (1989: 48), former executive secretary, economic commission of Africa [ECA], one of the causes of development crisis in Africa is that "country after country thus deserted Africa's indigenous strategy in favor of the one propounded by as good for Africa by the Breton Woods institutions". It is evident that Africa's protracted crisis of development has very strong historical roots in the form of colonial legacy and also partly-inflicted. Nwoye (2000: 33) examines the nature and profile of this root cause:

Disarticulated and weak economic base: A common feature of African economies is that they have very weak and incoherent base. As a result, their development is highly dependent on a global economic systems dominated by the developed capitalist economies of Europe and north America. In that challenge, those societies are saying that they must be the choosers of the development they need, they must be the implementers and judges of any development in their area. It is only when development whether spiritual, moral economic or political is beautifully integrated in the cultural values of a given people that it makes sense, is appreciated and considered lasting because it has become part and parcel of a given society. It is obvious why excluding culture leads to ignoring people in development in Africa. Culture is a way of life of the people-the way they engage themselves with the simplicity and complexity of their socio-economic spiritual and technological existence. Ignoring people or marginalizing people from participating in development has been one of the barriers of the banes of underdevelopment in Africa. According to Obiora (2001: 19), there are latent and obvious factors which hinder people's participation in development:

1) Elitism and Expertism. "A know it all culture"-which close the mind and stops it from being open and to search for new ideas, emphasis on Externalism and Quick Results-emphasizes external as parts of development to the exclusion of the mental ability to appreciate the same and part it to good use.

2) Bureaucratic Methods of work. Bureaucracy is interested in control and centralization of prove-people's participation cannot be encouraged nor designed.

3) Underestimation of people and lack of trust. Reject for people, however simple or poor and deep trust in them and their ability to solve their own problems are rare characteristics among the so-called educated and better off class of people.

4) Dislike for public accountability... involvement of people would mean their right to know everything including the finds used...

5) Marginalization of development education... because of the great demand to development and the urgency to offer solutions to Africa problems of hunger, malnutrition, disease, dies poverty, many people involved in development adopt an attitude that has o time energy or need to expose the suffering or the poor to development education or awareness... 
6) Ignoring the cultural factor in development-as genuine development can take place in Africa without having a culture. Context, as such people content...

\section{Recommendation/Conclusion}

Having come this far in this paper, we can confidently take a stand and define development (Ike \& The Africa civil Society Inititative, 2001: 71) which Africa can use and apply to the problems of bad governance and poverty in the continent in a creative cultural way that shakes the old paradigmatic way of seeing it in Africa either by African scholars or outsiders operating from Africa. This grassroots development concept sees it as

A multi-dimensional people-centered process. It aims to create conditions whereby each human being can realize his or her potential for political, social and economic fulfillment, in harmony with the common good. The rights, obligations and participation of individuals are central to this process and its objectives. The first priority is the eradication of poverty. This involves empowering people to gain control over their own lives and obtain the resources required to meet their basic needs, without destroying the environment. Genuine development is a grass root bottom-up process, where local communities are the key players. Economic activity should be managed by people, and should respect the limitations of a fragile and non-renewable environment. The market may be a means to achieve these goals, but it is not an end in self.

With this adoption of a working definition of development for Africa, let us say that development is about people, about culture and people's aspirations for a better life. We should set up an African strategic team that will design a development framework for Africa drawn from the different universities in Africa, NGO's, research organizations, the FBO's, government and labor whose main task is to:

1) use this working definition to establish a new theoretical framework with which African intellectual and practitioners can apply in the class and in the field;

2) use this to design a new framework for a people-centered government development blue print which will be used in African states to design policy, implement, monitor and evaluate same by the people.

3 ) use it to design a new pro-people electoral system to directly empower the African poor.

4) use it to change the curricula of artisanship, development and social science education in African institution of learning.

5) organize a regular African mullenization seminar in on development changes sponsored by the United Nations.

6) involve Africans in the Diasporas in designing innovative frontiers for African development.

7) establish an innovative centre for African development, governance and poverty reduction and use the agency of A.U, NEPAD, to circulate and apply new development framework and benchmarks across Africa.

8) sponsor university research agencies such as the institute of African studies, centre for peace-building and poverty, reduction, University of Nigeria (CEPPERUNN) and so such as the Catholic Institute for Development Justice and peace (CIDJAP).

9) that state across Africa should form economic teams made up of scholars and developmental scholars who have properly integrated the ingredients of the new African development theory model frameworks and benchmarks for monitoring and evaluating evaluative programs and projects.

10) finally, set up an African university team for development and the mirror of the way of life of the people of Africa in asp rational, sociological, political and technological terms for measurable results in their lives which can reduce poverty, deliver desirable dividends of democracy and assist Africa to attain the millennium development goals before 2015. The name of that new African theory, momentum and initiative is what I call "the polarization of African development in the $21^{\text {st }}$ century".

In conclusion, I would like to quote the views of Professor Obiora (2003: 29) on poverty in Africa: Poverty is not God determined. It is man-made if is not a fortuitous self-inflicted condition but rather a result of processes at work within the society if we so desire, we can eradicate poverty. In summary the problems which accentuate poverty and underdevelopment of Africa according to Ike is as follows:

- Lack of access to capital and resources for the handless and asset less the majority I are unable to provide the collateral required to access loans from the commercial banks.

- Lack of funding to build the capacity of community based organization and SME's to carry out projects promoting self reliance and self help. 
- Lack of affordable training and capacity building programs for courses the poor.

- Poor infrastructure and inadequate provisions by governments.

- Large spread poverty and the practical erosion of the middle class.

- Marginalization of women and youths.

- Poor institutional and infrastructure of indigenous enterprises and microfinance intermediaries.

- Lack of integration of the informal sector into the economy and lack of coordination of efforts of artisans, youths, women and petty traders. Their interests and livelihood issues are often neglected by the larger macro economic factors, and their income is not even considered in the computation of the GNP per capital.

As a follow-up to this article, I would want the various scholars of development studies both of Africa and non-African origin in Europe to start working upon the seminal ideas contained in this article that will explore these initiatives under the propelling force and need for a new paradigm and suggest the way forward for African development problems. This will help the African state to empower Africans and Africa to effectively emerge in the new millennium as development giant working as partners with other peoples and cultures of the world with their own home grown development paradigm.

\section{References}

Adedeji, A. (1989). The African Alternative Programme for Socio-Economic Recovery and Transformation [AAF-SAP]. Addis Ababa: E/ECA/CM.

Adedeji, A. (1996). Africa within the World: Beyond Dispossession and Dependence.

Areji, A. (2005). Europcentricity and Globalization culled from UCHE. Journal of the Department of Philoophy, 2, 55-56.

Basel, T. (2013). Human Development as Human Value-An African Paradigm. Nsukka: Cepper Press, University of Nigeria.

Blomstrom, M. B. (1978). Development Theory in Transition—The Dependency Debate and Beyond: Third World Responses. London: Zed Books.

Chachage, C. S. L. (1994). Discourse on Development among African Philosophers. In Himmestrand et al., Eds., African Perspectives on Development (p. 51). London: St Marins Press.

Cribson, J. H. (1961). The Remaking of Man in Africa. London: Oxford Press.

Dukor, M. (2010). Theistic Humanism of African Philosophy-The Great Debate on Substance and Methodology of African philosophy. Saarbrucken: Lambert Academic Publishing.

Esedese, P. O. (1978). The Emergence of Pan-African Ideas in Themes in African Social and Political Thought. Enugu: Fourth Dimension Publishers.

Himmelstrand, U. et al. (1988). In Search of New Paradigms-African Perspectives on Development, op cit. ps. CA New Framework for African Development.

Hountondy, Y. (1983). African Philosophy: Myth and Reality. London: Hutchion prers, 102.

Moses, M. (2007). African Philosophy: End of a Controversy? Ile Ife: OAU Press.

Mudimbe, V. (1984). African Gnosis: Philosophy and the Order of Knowledge. Los Angeles: African Studies Association.

NEEDS (2003). NEEDS Stands for the Nigerian Economic Empowerment Development Strategy Which Was Nigeria's Strategy and Plan to Bring about Development and Reduce Poverty among the Nigerian Poor. It Had Parallel Programs for at the State and Local Government Levels Known as SEEDS and LEEDS Respectively (State Economic Empowerment Development Strategy Local Economic Empowerment Development Strategy) NEEDS Was Nigerian Elite's Version of a World Bank Directed Poverty Reduction and Development Blue Print It Was Supposed to Be Country-Owned Home Grown.

Nwoye, K. O. (2000). Corruption, Leadership and the Dialectics of Development-An Exploratory Perspective. Enugu: Associated Co. Ltd., 50.

Nzongola \& Ntalaja (1989). The African Crisis: The Way out. African Studies Review, 32.

Obiora, I. (2000). Development Is about People. CA New Framework for African Development. Enugu: CIDJAP Press, 1-3.

Obiora, I. (2001). This Meaning Was Adopted at June 1994 in a Conference Titled "RETHINKING BRETON WOODS", Held in Washington D.C, and Attended by Theologians, Economists, Historians, Lawyers, Sociologists, NGO’s, FBO’s, FBV's and Churches from 20 Countries. Obiora Ike and Edoziem Enterprise Development Cooperation, Enugu: CIDJAP Press, iii.

Obiora, I. (2003). Development Is about People, Business Is about Ethics. Enugu: CIDJAP Press. 
Omoyibo, N. (1998). Philosophy as a Tool for Sustainable Development: A Contemporary Issue in Nigerian Educational System. Delta State University, Abraka, African Journal of Social Sciences, 1.

Onyeocha, I. P. (2011). Africa-The Country, the Concept and the Horizon. Amazon Publishers.

Oruka, H. O. (1985). Punishment and Tenorism in Africa. Nairobi: Kenya Literature Review.

Peers, D. (1972). What Are We Trying to Measure. Journal of Development Studies, 8, 21-36.

Perroux, F. (1964). El liderazgo norteamericano. eBook, François Perroux, 1964, Search (Open Library) by François 1 Edition, First Published in 1964.

President Bharrat Jaged, the President's Release of the Communiqué Issued afar the Commonwealth Meeting at Their London Secretariat on June as Reported on the First Page of Guardian of Wednesday, 11th June 2008, 1-2.

Samuel, C. (1998). The Development Debates \& The Crisis of Development Theories. Tanzania: Catholic Press.

Schumpeter, J. (1912). Schumpeter in His “Theorie de Wirtschafilishcme Entwicklung”.

Temples, P. (1976). “Placide Temples” Bantu Philosophy.

The World Commission on Environment and Development (1987). Defined Sustainable. 
Scientific Research Publishing (SCIRP) is one of the largest Open Access journal publishers. It is currently publishing more than 200 open access, online, peer-reviewed journals covering a wide range of academic disciplines. SCIRP serves the worldwide academic communities and contributes to the progress and application of science with its publication.

Other selected journals from SCIRP are listed as below. Submit your manuscript to us via either submit@scirp.org or Online Submission Portal.
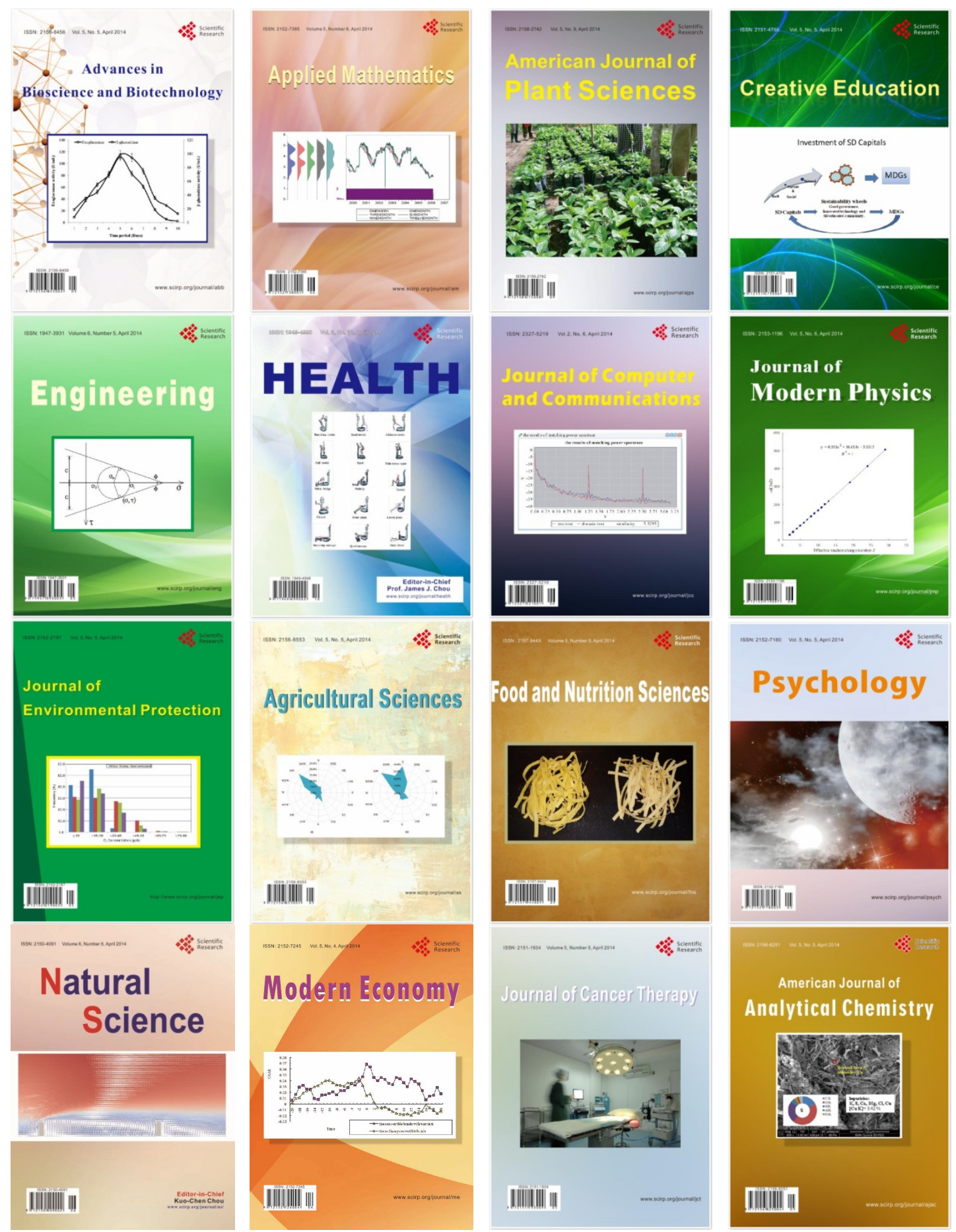